\title{
Shewanella haliotis sp. nov., isolated from the gut microflora of abalone, Haliotis discus hannai
}

Correspondence

Chi Nam Seong

scnu@scnu.ac.kr

\section{Duwoon Kim, ${ }^{1}$ Keun Sik Baik, ${ }^{2}$ Mi Sun Kim, ${ }^{2}$ Bok-Mi Jung, ${ }^{1}$ Tai-Sun Shin, ${ }^{1}$ Gyu-Hwa Chung, ${ }^{3}$ Moon Soo Rhee ${ }^{4}$ and Chi Nam Seong ${ }^{2}$}

\author{
${ }^{1}$ Division of Food Science and Aqualife Medicine, Chonnam National University, Yeosu 550-749, \\ Republic of Korea \\ ${ }^{2}$ Department of Biology, College of Natural Sciences, Sunchon National University, \\ Suncheon 540-742, Republic of Korea \\ ${ }^{3}$ Department of Biotechnology, Chonnam National University, Yeosu 550-749, Republic of Korea \\ ${ }^{4}$ Korean Collection for Type Cultures, Korea Research Institute of Bioscience and Biotechnology, \\ Daejeon 305-600, Republic of Korea
}

\begin{abstract}
A motile, rod-shaped, pink-orange pigmented bacterium, designated strain $\mathrm{DW} 01^{\top}$, was isolated from the gut microflora of abalone collected from the South Sea (Republic of Korea). Cells were Gram-negative, facultatively anaerobic, catalase- and oxidase-positive. The major fatty acids were iso- $\mathrm{C}_{15: 0}(17.7 \%), \mathrm{C}_{16: 0}(13.4 \%)$, iso- $\mathrm{C}_{15: 0} 2-\mathrm{OH}$ and/or $\mathrm{C}_{16: 1} \omega 7 \mathrm{c}(12.5 \%)$ and $\mathrm{C}_{17: 1} \omega 8 c(10.7 \%)$. The DNA G $+\mathrm{C}$ content was $53.7 \mathrm{~mol} \%$. A phylogenetic tree based on the $16 \mathrm{~S}$ rRNA gene sequences showed that strain DW01 ${ }^{\top}$ forms a lineage of the genus Shewanella and is closely related to Shewanella algae ATCC $51192^{\top}$ ( $98.3 \%$ sequence similarity) and to other members of the genus Shewanella (91.0-94.9\%). The phenotypic characteristics and DNA-DNA hybridization relatedness data indicate that strain $\mathrm{DW} 01^{\top}$ should be distinguished from S. algae ATCC $51192^{\top}$. On the basis of the data presented in this study, strain DW01 ${ }^{\top}$ represents a novel species, for which the name Shewanella haliotis sp. nov. is proposed. The type strain is DW01 ${ }^{\top}\left(=\right.$ KCTC $\left.12896^{\top}=J C M 14758^{\top}\right)$.
\end{abstract}

The genus Shewanella is a member of the class Gammaproteobacteria (Anzai et al., 2000) and comprises a group of Gram-negative, motile, rod-shaped, oxidasepositive, non-fermentative and facultatively anaerobic aquatic and marine bacteria (Bowman, 2005; Gauthier et al., 1995; MacDonell \& Colwell, 1985; Venkateswaran et al., 1999). At the time of writing, the genus Shewanella comprised 45 recognized species (http://www.bacterio.cict.fr/s/shewanella.html). Strains of the genus Shewanella have been isolated from a variety of sources including marine environments (Venkateswaran et al., 1998; Nealson et al., 1991; Nogi et al., 1998; Ivanova et al., 2001, 2004a,b; Bozal et al., 2002; Skerratt et al., 2002; Yoon et al., 2004b; Gram et al., 1987; Stenstrom \& Molin, 1990; Gram \& Huss, 1996; Satomi et al., 2006, 2007; Lee et al., 2006; Satomi et al., 2003; Simidu et al., 1990; Yang et al., 2006), sediments (Myers \& Nealson, 1988; Venkateswaran et al., 1999; Toffin et al., 2004; Yoon et al., 2004a; Gao et al., 2006; Zhao et al., 2005, 2006; Miyazaki et al., 2006; Xiao et al., 2007; Yang et al., 2007), clinical samples (Brink et al., 1995; Nozue et al., 1992; Levin, 1972; Debois et al., 1975;

The GenBank/EMBL/DDBJ accession number for the 16S rRNA gene sequence of strain DWO1 ${ }^{\top}$ is EF178282.
Holmes et al., 1975), oilfield fluids (Semple \& Westlake, 1987) and activated sludge (Xu et al., 2005). They have also been implicated as opportunistic pathogens of humans and aquatic animals (Aguirre et al., 1994; Brink et al., 1995) and as the causal agents of proteinaceous food spoilage (Jorgensen \& Huß, 1989).

During the course of our study on gut microflora of abalone, a rod-shaped bacterial strain, designated $\mathrm{DW} 01^{\mathrm{T}}$, was isolated and subjected to a taxonomic investigation. On the basis of the polyphasic evidence, strain DW $01^{\mathrm{T}}$ represents a novel species of the genus Shewanella, for which the name Shewanella haliotis sp. nov. is proposed.

Strain $\mathrm{DW} 01^{\mathrm{T}}$ was isolated from an abalone sample collected from the South Sea near Yeosu $\left(34^{\circ} 44^{\prime} \mathrm{N}, 127^{\circ}\right.$ $44^{\prime}$ E) located in the Republic of Korea, during July 2006, using the standard dilution plating technique. Isolation was achieved using marine agar (MA; Difco) (Yang et al., 2006) at $30{ }^{\circ} \mathrm{C}$ for 7 days. The isolate was routinely cultured on MA and maintained as a glycerol suspension $(20 \%$ w/v) at $-80{ }^{\circ} \mathrm{C}$.

Bacterial DNA preparation, PCR amplification and sequencing of the 16S rRNA gene were carried out as described previously (Chun \& Goodfellow, 1995). The 


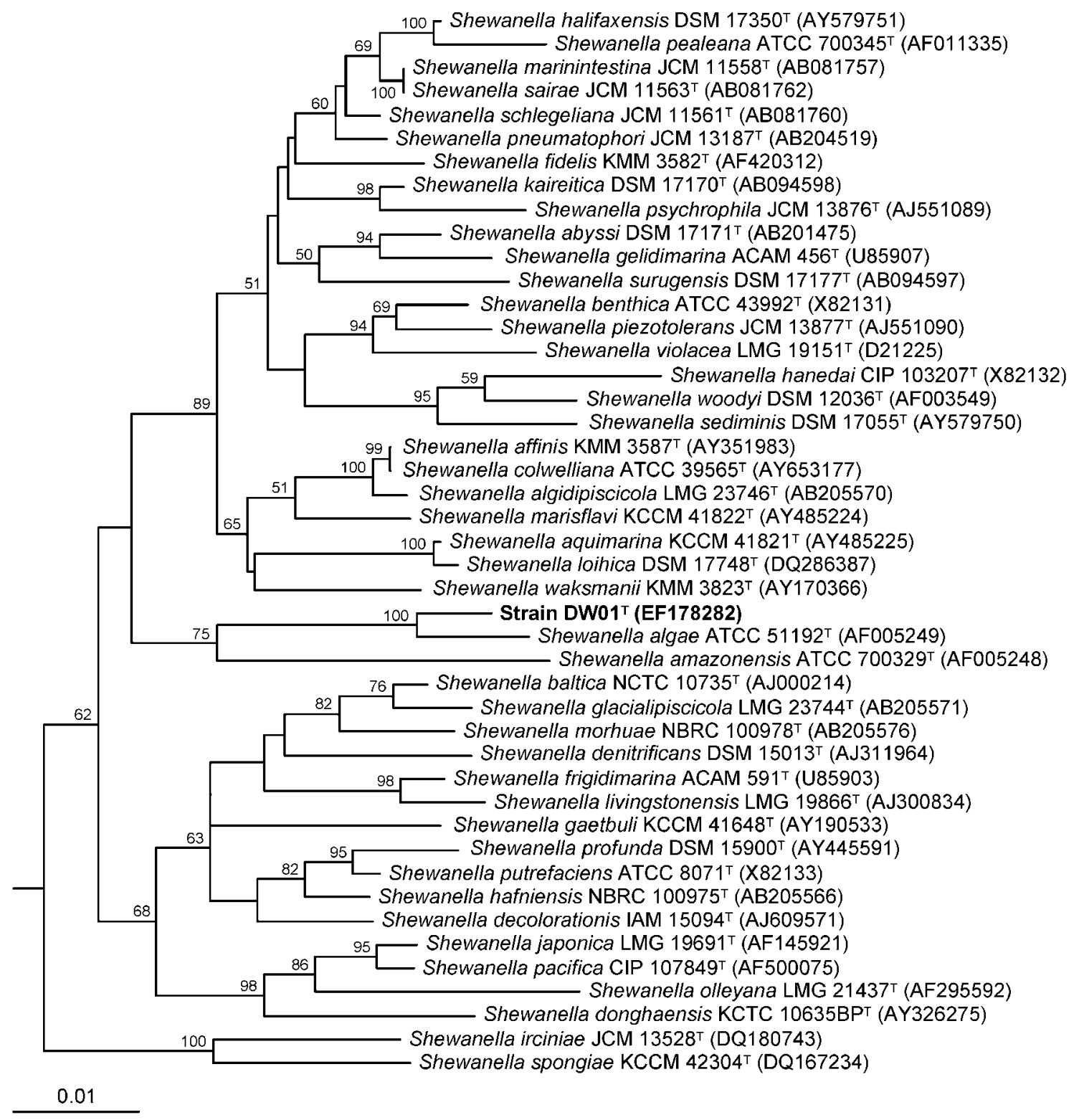

Fig. 1. Neighbour-joining tree based on the almost-complete $16 \mathrm{~S}$ rRNA gene sequences showing the relationship between strain DW01 ${ }^{\top}$ and members of the genus Shewanella. The percentage numbers at the nodes are the levels of bootstrap support based on neighbour-joining analyses of 1000 resampled datasets. The sequence of Vibrio cholerae ATCC 14035 ${ }^{\top}$ (Z21856) was used as an outgroup (not shown). Bar, 0.01 nucleotide substitutions per position.

resultant sequence of strain DW $01^{\mathrm{T}}$ was aligned manually against sequences obtained from the GenBank database. Phylogenetic trees were inferred from the regions available for all sequences (positions 38-1450; Escherichia coli numbering system) using the Fitch-Margoliash (Fitch \& Margoliash, 1967) and neighbour-joining (Saitou \& Nei, 1987) methods. Evolutionary distance matrices were generated according to Jukes \& Cantor (1969). The resultant neighbour-joining tree topology was evaluated by bootstrap analyses (Felsenstein, 1985) based on 1000 resamplings. Alignment and phylogenetic analyses were carried out using the jPHYDIT program (available at http:// chunlab.snu.ac.kr/jphydit/) and PAUP 4.0 (Swofford, 1998) as described previously (Chun et al., 2000).

Preliminary sequence comparison with the 16S rRNA gene sequences held in GenBank indicated that our isolate was related closely to members of the genus Shewanella. The newly determined sequence was then aligned manually against representatives of the genus Shewanella. Strain DW $01^{\mathrm{T}}$ showed the highest $16 \mathrm{~S}$ rRNA gene sequence similarity to Shewanella algae ATCC $51192^{\mathrm{T}}(98.3 \%)$, followed by Shewanella profunda DSM $15900^{\mathrm{T}}$ (94.9\%), Shewanella kaireitica DSM $17170^{\mathrm{T}}(94.4 \%)$ and Shewanella 
schlegeliana JCM $11561^{\mathrm{T}}(94.1 \%)$. To elucidate the phylogenetic relationship between the novel isolate and other species of the genus Shewanella, phylogenetic trees were constructed using two different tree-making algorithms. The neighbour-joining tree (Fig. 1) showed that strain $\mathrm{DW} 01^{\mathrm{T}}$ formed a monophyletic clade with $S$. algae ATCC $51192^{\mathrm{T}}$ with $100 \%$ bootstrap support.

Growth on various standard bacteriological media was tested by using nutrient agar (NA; Difco), tryptic soy agar (TSA; Difco) and R2A agar (Difco) according to the manufacturer's instructions. Cells of strain $\mathrm{DW} 01^{\mathrm{T}}$ grown on TSA at $30{ }^{\circ} \mathrm{C}$ for $3-7$ days were used for the physiological and biochemical tests. Motility was examined by observing the cells grown in wet mounts using phasecontrast microscope (Nikon TMS-F). The $\mathrm{pH}$ range ( $\mathrm{pH} 3-12)$, growth temperature $\left(4-42{ }^{\circ} \mathrm{C}\right), \mathrm{NaCl}$ tolerance $[0,1,2,3,5,10 \%(\mathrm{w} / \mathrm{v})]$ and growth in an anaerobic chamber $\left(\mathrm{CO}_{2} / \mathrm{H}_{2} / \mathrm{N}_{2}, 10: 10: 80\right.$; Sheldon Manufacturing) were checked using TSA, using up to 1 week incubation periods. Catalase and oxidase activities were determined using $3 \%(\mathrm{v} / \mathrm{v})$ hydrogen peroxide and Kovac's reagent (Kovacs, 1956), respectively. Other physiological and biochemical tests were performed using API 20E, API 20NE and API 50CH (bioMérieux). Enzymic activities were tested using API ZYM kit (bioMérieux) following the manufacturer's instructions. Antibiotic resistance was determined with the disc diffusion method. The results were interpreted according to the guidelines set forth by the National Committee for Clinical Laboratory Standards.

Strain DW01 ${ }^{\mathrm{T}}$ was facultatively anaerobic, Gram-negative, motile and rod-shaped. Colonies grown on TSA plates for 5 days at $30{ }^{\circ} \mathrm{C}$ were circular, convex, entire margin, smooth, opaque, pink-orange coloured and approximately $5.0 \mathrm{~mm}$ in diameter. The novel strain grew well on MA, TSA, plate count agar (PCA; Difco) and NA. On TSA medium, strain DW $01^{\mathrm{T}}$ was able to grow at $10-42{ }^{\circ} \mathrm{C}$. The detailed results of physiological and biochemical analyses are given in Table 1 and the species description. It is evident from Table 1 that there are several phenotypic characters that readily separate strain $\mathrm{DW} 01^{\mathrm{T}}$ from phylogenetically related species, namely $S$. algae and Shewanella amazonesis.

Cellular fatty acids of strain $\mathrm{DW} 01^{\mathrm{T}}$ were analysed as methyl esters by GLC according to the instructions of the Microbial Identification System (MIDI). The cellular fatty acid profile of strain DW $01^{\mathrm{T}}$ is described in Table 2. The $\mathrm{G}+\mathrm{C}$ content of the DNA was determined by using the thermal denaturation method of Marmur \& Doty (1962). The DNA G + C content of DW01 ${ }^{\mathrm{T}}$ was $53.7 \mathrm{~mol} \%$.

The taxonomic relationship between strain DW $01^{\mathrm{T}}$ and $S$. algae ATCC $51192^{\mathrm{T}}$ was further examined using DNADNA hybridization. Genomic relatedness was determined using a membrane filter technique (Seldin \& Dubnau, 1985) with a DIG High Prime DNA Labelling and Detection Starter kit II (Roche). When DNAs were used individually as labelled DNA probes for reciprocal hybridization experiments and conducted in duplicate, the DNA-DNA relatedness value between strain DW01 ${ }^{\mathrm{T}}$ and S. algae ATCC $51192^{\mathrm{T}}$ was $35.8 \%$. It is clear from the $16 \mathrm{~S}$ rRNA gene sequence and DNA-DNA hybridization data that strain DW $01^{\mathrm{T}}$ represents a novel species of the genus Shewanella (Wayne et al., 1987).

In addition, a number of physiological and chemotaxonomic characters clearly distinguished our isolate from other phylogenetically related species (Tables 1 and 2). Therefore, strain DW01 ${ }^{\mathrm{T}}$ should be classified as a novel species of the genus Shewanella, for which the name Shewanella haliotis sp. nov. is proposed.

\section{Description of Shewanella haliotis sp. nov.}

Shewanella haliotis (ha.li.o'tis. N.L. gen. n. haliotis of Haliotis, the scientific name of abalones).

Cells are rod-shaped, Gram-negative and facultatively anaerobic bacterium. Cells grow best on media such as

Table 1. Phenotypic characteristics that differentiate strain $\mathrm{DW} 1^{\top}$ from its phylogenetic neighbours of Shewanella species

Strains: 1, DW01 ${ }^{\mathrm{T}}$; 2, S. algae ATCC $51192^{\mathrm{T}}$; 3, S. amazonensis ATCC $700329^{\mathrm{T}}$. Data from Khashe \& Janda (1998), Nozue et al. (1992), Venkateswaran et al. (1998) and this study. +, Positive; -, negative; $\mathrm{W}$, weakly positive; ND, no data available. All strains are Gramnegative, rod-shaped, motile and positive for catalase, oxidase, $\mathrm{H}_{2} \mathrm{~S}$ production, gelatinase and reduction of nitrates to nitrites. All strains are negative for the utilization of D-glucose, adipate, glycerol, mannitol, sorbitol, maltose, lactose and sucrose as carbon sources. Two species (1 and 2) are resistant to vancomycin (30 $\mu$ g per disc), ampicillin $(10 \mu \mathrm{g}$ per disc) and penicillin (10 U per disc).

\begin{tabular}{|lccc|}
\hline Characteristic & $\mathbf{1}$ & $\mathbf{2}$ & $\mathbf{3}$ \\
\hline Habitat & Abalone & Salt marshes & Mud \\
Colony colour & Pink-orange & Pink & Pink \\
Growth at $4{ }^{\circ} \mathrm{C}$ & - & - & + \\
Growth at $42{ }^{\circ} \mathrm{C}$ & + & + & - \\
Tolerance to $6 \% \mathrm{NaCl}$ & + & + & - \\
Ornithine decarboxylase & + & + & - \\
Citrate utilization & - & - & + \\
Reduction of nitrates to & + & + & - \\
nitrites & & & \\
Acidification of glucose & - & $\mathrm{W}$ & - \\
Assimilation of: & & & \\
$\quad$ Mannose & - & + & + \\
Caprate & + & + & - \\
$\quad$ Malate & + & - & - \\
$\quad$ Fructose & - & + & + \\
Antibiotic resistance $(\mu \mathrm{g}$ per disc): & & & \\
Polymyxin B $(300)$ & $\mathrm{R}$ & $\mathrm{S}^{*}$ & ND \\
DNA G + C content $(\mathrm{mol} \%)$ & 53.7 & 54.0 & 51.7 \\
\hline
\end{tabular}

${ }^{\star}$ Data from this study. 
Table 2. Cellular fatty acid composition (\%) of strain DW01 and its phylogenetic neighbours of Shewanella species

Strains: 1, DW01 ${ }^{\mathrm{T}}$; 2, S. algae ATCC $51192^{\mathrm{T}}$; 3, S. amazonensis ATCC $700329^{\mathrm{T}}$. Data from Venkateswaran et al. (1998) and this study. Values are percentages of total fatty acids. -, Fatty acid not present; tr, trace amount $(<1 \%)$; ND, no data available.

\begin{tabular}{|c|c|c|c|}
\hline Fatty acid & 1 & 2 & 3 \\
\hline \multicolumn{4}{|c|}{ Straight-chain saturated } \\
\hline $\mathrm{C}_{12: 0}$ & 2.21 & 1.93 & ND \\
\hline $\mathrm{C}_{14: 0}$ & 1.91 & 1.19 & 1.43 \\
\hline $\mathrm{C}_{15: 0}$ & 2.75 & 3.72 & 9.17 \\
\hline $\mathrm{C}_{16: 0}$ & 13.43 & 11.56 & 6.11 \\
\hline $\mathrm{C}_{17: 0}$ & 2.49 & 2.99 & 3.95 \\
\hline $\mathrm{C}_{18: 0}$ & 6.54 & 3.31 & $\operatorname{tr}$ \\
\hline $\mathrm{C}_{12: 0} 3-\mathrm{OH}$ & 1.96 & - & - \\
\hline \multicolumn{4}{|l|}{ Branched saturated } \\
\hline iso- $\mathrm{C}_{13: 0}$ & 4.10 & 3.28 & 4.70 \\
\hline iso- $\mathrm{C}_{14: 0}$ & 1.11 & $\operatorname{tr}$ & 1.55 \\
\hline iso- $\mathrm{C}_{15: 0}$ & 17.72 & 20.72 & 26.69 \\
\hline iso- $\mathrm{C}_{16: 0}$ & $\operatorname{tr}$ & $\operatorname{tr}$ & 1.41 \\
\hline iso- $\mathrm{C}_{17: 0}$ & 1.62 & 1.79 & 1.80 \\
\hline iso- $\mathrm{C}_{13: 0} 3-\mathrm{OH}$ & - & 2.87 & - \\
\hline \multicolumn{4}{|l|}{ Monounsaturated } \\
\hline $\mathrm{C}_{16: 1} \omega 7 c$ & - & - & 14.65 \\
\hline $\mathrm{C}_{16: 1} \omega 9 c$ & 1.11 & 1.29 & $\operatorname{tr}$ \\
\hline $\mathrm{C}_{17: 1} \omega 6 c$ & $\operatorname{tr}$ & $\operatorname{tr}$ & 2.43 \\
\hline $\mathrm{C}_{17: 1} \omega 8 c$ & 10.70 & 11.81 & 23.45 \\
\hline $\mathrm{C}_{18: 1} \omega 7 c$ & 5.44 & 4.81 & 4.46 \\
\hline $\mathrm{C}_{18: 1} \omega 9 c$ & 4.52 & 4.09 & 1.39 \\
\hline Summed feature $1^{*}$ & 1.50 & 1.85 & $\mathrm{ND}$ \\
\hline Summed feature $2^{\star}$ & 1.10 & 1.16 & $\mathrm{ND}$ \\
\hline Summed feature $3^{*}$ & 12.45 & 13.49 & ND \\
\hline
\end{tabular}

*Summed features represent groups of two fatty acids that could not be separated by GLC with the MIDI system. Summed feature 1 contained $\mathrm{C}_{13: 0}$ 3-OH and iso- $\mathrm{C}_{15: 1} \mathrm{I} / \mathrm{H}$. Summed feature 2 contained $\mathrm{C}_{14: 0} 3-\mathrm{OH}$ and iso- $\mathrm{C}_{16: 1}$ I. Summed feature 3 contained $\mathrm{C}_{16: 1} \omega 7 c$ and iso- $\mathrm{C}_{15: 0} 2-\mathrm{OH}$.

MA, TSA, PCA and NA, but weakly on R2A. Colonies on TSA are circular, low-convex, entire margin, smooth, opaque, pink-orange coloured and approximately $5.0 \mathrm{~mm}$ in diameter after 5 days at $30{ }^{\circ} \mathrm{C}(\mathrm{pH} 7)$. Cells are motile rods and $0.5-0.7 \times 2.0-4.3 \mu \mathrm{m}$ in size. Growth occurs in 0 $10 \%(\mathrm{w} / \mathrm{v}) \mathrm{NaCl}$ (optimum $4 \%$ ). Growth occurs in $\mathrm{pH} 5$ 11 (optimum $\mathrm{pH} 7$ ) and at $10-42{ }^{\circ} \mathrm{C}$ (optimum $37{ }^{\circ} \mathrm{C}$ ). Oxidase-positive, catalase-positive. Reduces nitrate to nitrite. Negative for glucose fermentation. Does not produce arginine dihydrolase, urease, lysine decarboxylase, $\beta$-galactosidase or tryptophan deaminase. Produces $\mathrm{H}_{2} \mathrm{~S}$ but not acetoin or indole. Produces gelatinase, $\alpha$-chymotrypsin, alkaline phosphatase and ornithine decarboxylase, but not lipase (C14). Utilizes the following substrates as sole carbon and energy sources: $\mathrm{N}$-acetylglucosamine, caprate and malate. Does not utilize the following substrates: D-glucose, galactose, fructose, mannose, melibiose, D-arabinose, L-arabinose, D-xylose, aesculin, salicin, glycerol, ribose, adonitol, sorbose, dulcitol, inositol, mannitol, sorbitol or inulin. Cells are sensitive to ( $\mu \mathrm{g}$ per disc, unless otherwise indicated): amikacin (30), gentamicin (10), streptomycin (10), tetracycline (30), erythromycin (15), chloramphenicol (30), kanamycin (30) and nalidixic acid (30) but resistant to ampicillin (10), vancomycin (30), polymyxin B (300) and penicillin (10 U). Other physiological and biochemical characteristics are given in Table 1. Major fatty acids are iso- $\mathrm{C}_{15: 0}(17.7 \%), \mathrm{C}_{16: 0}(13.4 \%)$, iso- $\mathrm{C}_{15: 0} 2-\mathrm{OH}$ and/or $\mathrm{C}_{16: 1} \omega 7 c(12.5 \%)$ and $\mathrm{C}_{17: 1} \omega 8 c$ $(10.7 \%)$, and complete fatty acid composition is given in Table 2. The DNA G+C content is $53.7 \mathrm{~mol} \%$.

The type strain, DW01 ${ }^{\mathrm{T}}\left(=\right.$ KCTC $\left.12896^{\mathrm{T}}=\mathrm{JCM} 14758^{\mathrm{T}}\right)$, was isolated from the gut microflora of abalone collected from the South Sea, Republic of Korea.

\section{Acknowledgements}

This research was supported by the Programme for the Training of Graduate Students in Regional Innovation, which was conducted by the Korean Government's Ministry of Commerce Industry and Energy and this work was also supported by the BK21 (the Ministry of Education and Human Resources Development), Republic of Korea. Special thanks are extended to Dr J. P. Euzéby for his recommendation concerning the Latin etymology for strain $\mathrm{DW} 01^{\mathrm{T}}$.

\section{References}

Aguirre, A. A., Balazas, G. H., Zimmerman, B. \& Spraker, T. R. (1994). Evaluation of Hawaiian green turtles (Cheledonia mydas) for potential pathogens associated with fibropapillomas. J Wild Dis 30, 8-15.

Anzai, Y., Kim, H., Park, J. Y., Wakabayashi, H. \& Oyaizu, H. (2000). Phylogenetic affiliation of the pseudomonads based on 16S rRNA sequence. Int J Syst Evol Microbiol 50, 1563-1589.

Bowman, J. P. (2005). Genus XIII. Shewanella MacDonell and Colwell 1986, 355 ${ }^{\mathrm{VP}}$ (Effective publication: MacDonell and Colwell 1985, 180). In Bergey's Manual of Systematic Bacteriology, 2nd edn, vol. 2, part B, pp. 480-491. Edited by D. J. Brenner, N. R. Crieg, J. T. Staley \& G. M. Garrity. New York: Springer.

Bozal, N., Montes, M. J., Tudela, E., Jiménez, F. \& Guinea, J. (2002). Shewanella frigidimarina and Shewanella livingstonensis sp. nov. isolated from Antarctic coastal areas. Int J Syst Evol Microbiol 52, 195-205.

Brink, A. J., van Straten, A. \& van Rensburg, A. J. (1995). Shewanella (Pseudomonas) putrefaciens bacteremia. Clin Infect Dis 20, 1327-1332.

Chun, J. \& Goodfellow, M. (1995). A phylogenetic analysis of the genus Nocardia with 16S rRNA gene sequences. Int J Syst Bacteriol 45, 240-245.

Chun, J., Bae, K. S., Moon, E. Y., Jung, S. O., Lee, H. K. \& Kim, S. J. (2000). Nocardiopsis kunsanensis sp. nov., a moderately halophilic actinomycete isolated from a saltern. Int J Syst Evol Microbiol 50, 1909-1913.

Debois, J., Degreef, H., Vandepitte, J. \& Spaepen, J. (1975). Pseudomonas putrefaciens as a cause of infection in humans. J Clin Pathol 28, 993-996.

Felsenstein, J. (1985). Confidence limits on phylogenies: an approach using the bootstrap. Evolution 39, 783-791. 
Fitch, W. M. \& Margoliash, E. (1967). Construction of phylogenetic trees. Science 155, 279-284.

Gao, H., Obraztova, A., Stewart, N., Popa, R., Fredrickson, J. K., Tiedje, J. M., Nealson, K. H. \& Zhou, J. (2006). Shewanella loihica sp. nov., isolated from iron-rich microbial mats in the Pacific Ocean. Int J Syst Evol Microbiol 56, 1911-1916.

Gauthier, G., Gauthier, M. \& Christen, R. (1995). Phylogenetic analysis of the genera Alteromonas, Shewanella, and Moritella using genes coding for small-subunit rRNA sequences and division of the genus Alteromonas into two genera, Alteromonas (emended) and Pseudoalteromonas gen. nov., and proposal of twelve new species combinations. Int J Syst Bacteriol 45, 755-761.

Gram, L. \& Huss, H. H. (1996). Microbiological spoilage of fish and fish products. Int J Food Microbiol 33, 121-137.

Gram, L., Trolle, G. \& Huss, H. H. (1987). Detection of specific spoilage bacteria from fish stored at low $\left(0{ }^{\circ} \mathrm{C}\right)$ and high $\left(20{ }^{\circ} \mathrm{C}\right)$ temperatures. Int J Food Microbiol 4, 65-72.

Holmes, B., Lapage, S. P. \& Malnick, H. (1975). Strains of Pseudomonas putrefaciens from clinical material. J Clin Pathol 28, 149-155.

Ivanova, E. P., Sawabe, T., Gorshkova, N. M., Svetashev, V. I., Mikhailov, V. V., Nicolau, D. V. \& Christen, R. (2001). Shewanella japonica sp. nov. Int J Syst Evol Microbiol 51, 1027-1033.

Ivanova, E. P., Gorshkova, N. M., Bowman, J. P., Lysenko, A. M., Zhukova, N. V., Sergeev, A. F., Mikhailov, V. V. \& Nicolau, D. V. (2004a). Shewanella pacifica sp. nov., a polyunsaturated fatty acidproducing bacterium isolated from sea water. Int J Syst Evol Microbiol 54, 1083-1087.

Ivanova, E. P., Nedashkovskaya, O. I., Sawabe, T., Zhukova, N. V., Frolova, G. M., Nicolau, D. V., Mikhailov, V. V. \& Bowman, J. P. (2004b). Shewanella affinis sp. nov., isolated from marine invertebrates. Int J Syst Evol Microbiol 54, 1089-1093.

Jorgensen, B. R. \& Huß, H. H. (1989). Growth and activity of Shewanella putrefaciens isolated from spoiling fish. Int $J$ Food Microbiol 9, 51-62.

Jukes, T. H. \& Cantor, C. R. (1969). Evolution of protein molecules. In Mammalian Protein Metabolism, vol. 3, pp. 21-132. Edited by H. N. Munro. New York: Academic Press.

Khashe, S. \& Janda, J. M. (1998). Biochemical and pathogenic properties of Shewanella alga and Shewanella putrefaciens. J Clin Microbiol 36, 783-787.

Kovacs, N. (1956). Identification of Pseudomonas pyocyanea by the oxidase reaction. Nature 178, 703.

Lee, O. O., Lau, S. C. K., Tsoi, M. M. Y., Li, X., Plakhotnikova, I., Dobretsov, S., Wu, M. C. S., Wong, P.-K., Weinbauer, M. \& Qian, P.-Y. (2006). Shewanella irciniae sp. nov., a novel member of the family Shewanellaceae, isolated from the marine sponge Ircinia dendroides in the Bay of Villefranche, Mediterranean Sea. Int J Syst Evol Microbiol 56, 2871-2877.

Levin, R. E. (1972). Correlation of DNA base composition and metabolism of Pseudomonas putrefaciens isolates from food, human clinical specimens, and other sources. Antonie van Leeuwenhoek 38, 121-127.

MacDonell, M. T. \& Colwell, R. R. (1985). Phylogeny of the Vibrionaceae and recommendation for two new genera, Listonella and Shewanella. Syst Appl Microbiol 6, 171-182.

Marmur, J. \& Doty, P. (1962). Determination of the base composition of deoxyribonucleic acid from its thermal denaturation temperature. J Mol Biol 5, 109-118.

Miyazaki, M., Nogi, Y., Usami, R. \& Horikoshi, K. (2006). Shewanella surugensis sp. nov., Shewanella kaireitica sp. nov. and Shewanella abyssi sp. nov., isolated from deep-sea sediments of Suruga Bay, Japan. Int J Syst Evol Microbiol 56, 1607-1613.

Myers, C. R. \& Nealson, K. H. (1988). Manganese reduction bacteria and growth with manganese oxide as the sole electron acceptor. Science 240, 1319-1321.

Nealson, K. H., Myers, C. R. \& Wimpee, B. (1991). Isolation and identification of manganese reducing bacteria, and estimates of microbial manganese reducing potential in the Black Sea. Deep Sea Res 38, S907-S920.

Nogi, Y., Kato, C. \& Horikoshi, K. (1998). Taxonomic studies of deepsea barophilic Shewanella strains and description of Shewanella violacea sp. nov. Arch Microbiol 170, 331-338.

Nozue, H., Hayashi, T., Hashimoto, Y., Ezaki, T., Hamasaki, K., Ohwada, K. \& Terawaki, Y. (1992). Isolation and characterization of Shewanella alga from human clinical specimens and emendation of the description of S. alga Simidu et al., 1990, 335. Int J Syst Evol Microbiol 42, 628-634.

Saitou, N. \& Nei, M. (1987). The neighbor-joining method: a new method for reconstructing phylogenetic trees. Mol Biol Evol 4, 406-425.

Satomi, M., Oikawa, H. \& Yano, Y. (2003). Shewanella marinintestina sp. nov., Shewanella schlegeliana sp. nov. and Shewanella sairae sp. nov., novel eicosapentaenoic-acid-producing marine bacteria isolated from sea-animal intestines. Int J Syst Evol Microbiol 53, 491-499.

Satomi, M., Vogel, B. F., Gram, L. \& Venkateswaran, K. (2006). Shewanella hafniensis sp. nov. and Shewanella morhuae sp. nov., isolated from marine fish of the Baltic Sea. Int J Syst Evol Microbiol 56, 243-249.

Satomi, M., Vogel, B. F., Venkateswaran, K. \& Gram, L. (2007). Description of Shewanella glacialipiscicola sp. nov. and Shewanella algidipiscicola sp. nov., isolated from marine fish of the Danish Baltic Sea, and proposal that Shewanella affinis is a later heterotypic synonym of Shewanella colwelliana. Int J Syst Evol Microbiol 57, 347-352.

Seldin, L. \& Dubnau, D. (1985). Deoxyribonucleic acid homology among Bacillus polymyxa, Bacillus macerans, Bacillus azotofixans, and other nitrogen-fixing Bacillus strains. Int J Syst Bacteriol 35, 151-154.

Semple, K. M. \& Westlake, D. W. S. (1987). Characterization of ironreducing Alteromonas putrefaciens strains from oil field fluids. Can J Microbiol 35, 925-931.

Simidu, U., Kita-Tsukamoto, K., Yamasato, T. \& Yotsu, M. (1990). Taxonomy of four marine bacterial strains that produce tetrodotoxin. Int J Syst Bacteriol 40, 331-336.

Skerratt, J. H., Bowman, J. P. \& Nichols, P. D. (2002). Shewanella olleyana sp. nov., a marine species isolated from a temperate estuary which produces high levels of polyunsaturated fatty acids. Int J Syst Evol Microbiol 52, 2101-2106.

Stenstrom, I. M. \& Molin, G. (1990). Classification of the spoilage flora of fish, with special reference to Shewanella putrefaciens. J Appl Bacteriol 68, 601-618.

Swofford, D. L. (1998). PAUP: phylogenetic analysis using parsimony, version 4. Sunderland, MA: Sinauer Associates.

Toffin, L., Bidault, A., Pignet, P., Tindall, B. J., Slobodkin, A., Kato, C. \& Prieur, D. (2004). Shewanella profunda sp. nov., isolated from deep marine sediment of the Nankai Trough. Int J Syst Evol Microbiol 54, 1943-1949.

Venkateswaran, K., Dollhopf, M. E., Aller, R., Stackebrandt, E. \& Nealson, K. H. (1998). Shewanella amazonensis sp. nov., a novel metal-reducing facultative anaerobe from Amazonian shelf muds. Int J Syst Bacteriol 48, 965-972.

Venkateswaran, K., Moser, D. P., Dollhopf, M. E., Lies, D. P., Saffarini, D. A., MacGregor, B. J., Ringelberg, D. B., White, D. C., Nishijima, M. \& other authors (1999). Polyphasic taxonomy of the 
genus Shewanella and description of Shewanella oneidensis sp. nov. Int J Syst Bacteriol 49, 705-724.

Wayne, L. G., Brenner, D. J., Colwell, R. R., Grimont, P. A. D., Kandler, O., Krichevsky, M. I., Moore, L. H., Moore, W. E. C., Murray, R. G. E. \& other authors (1987). International Committee on Systematic Bacteriology. Report of the ad hoc committee on reconciliation of approaches to bacterial systematics. Int J Syst Bacteriol 37, 463-464.

Xiao, X., Wang, P., Zeng, X., Bartlett, D. H. \& Wang, F. (2007). Shewanella psychrophila sp. nov. and Shewanella piezotolerans sp. nov., isolated from west Pacific deep-sea sediment. Int J Syst Evol Microbiol 57, 60-65.

Xu, M., Guo, J., Cen, Y., Zhong, X., Cao, W. \& Sun, G. (2005). Shewanella decolorationis sp. nov., a dye-decolorizing bacterium isolated from activated sludge of a waste-water treatment plant. Int $J$ Syst Evol Microbiol 55, 363-368.

Yang, S.-H., Kwon, K. K., Lee, H.-S. \& Kim, S.-J. (2006). Shewanella spongiae sp. nov., isolated from a marine sponge. Int J Syst Evol Microbiol 56, 2879-2882.
Yang, S.-H., Lee, J.-H., Ryu, J.-S., Kato, C. \& Kim, S.-J. (2007). Shewanella donghaensis sp. nov., a psychrophilic, piezosensitive bacterium producing high levels of polyunsaturated fatty acid, isolated from deep-sea sediments. Int J Syst Evol Microbiol 57, 208-212.

Yoon, J. H., Kang, K. H., Oh, T. K. \& Park, Y. H. (2004a). Shewanella gaetbuli sp. nov., a slight halophile isolated from a tidal flat in Korea. Int J Syst Evol Microbiol 54, 487-491.

Yoon, J. H., Yeo, S. H., Kim, I. G. \& Oh, T. K. (2004b). Shewanella marisflavi sp. nov. and Shewanella aquimarina sp. nov., slightly halophilic organisms isolated from sea water of the Yellow Sea in Korea. Int J Syst Evol Microbiol 54, 2347-2352.

Zhao, J.-S., Manno, D., Beaulieu, C., Paquet, L. \& Hawari, J. (2005). Shewanella sediminis sp. nov., a novel $\mathrm{Na}^{+}$-requiring and hexahydro1,3,5-trinitro-1,3,5-triazine-degrading bacterium from marine sediment. Int J Syst Evol Microbiol 55, 1511-1520.

Zhao, J.-S., Manno, D., Leggiadro, C., O’Neil, D. \& Hawari, J. (2006). Shewanella halifaxensis sp. nov., a novel obligately respiratory and denitrifying psychrophile. Int J Syst Evol Microbiol 56, 205-212. 